\title{
Nonhomologous End-Joining Factor 1
}

National Cancer Institute

\section{Source}

National Cancer Institute. Nonhomologous End-Joining Factor 1. NCI Thesaurus. Code C88515.

Non-homologous end-joining factor 1 (299 aa, 33 kDa) is encoded by the human NHEJ1 gene. This protein is involved in both the repair of double-strand breaks in DNA and nonhomologous end-joining. 